\title{
Severe Deficiency of B Lymphocytes in Peripheral Blood from Multiple Myeloma Patients
}

\author{
Linda M. Pilarski, Michael J. Mant, \\ Bernard A. Ruether, and Andrew Belch \\ Department of Immunology and Department of Medicine, \\ University of Alberta, Edmonton, Alberta; Department of \\ Medicine, University of Calgary, Calgary, Alberta, Canada
}

bstract. A major problem in the assessment of circulating B lymphocytes in multiple myeloma is the extent to which cells with passively absorbed Ig contribute to the assay. We have analyzed peripheral blood B cell numbers in 51 patients in various treatment categories by using an assay that is not subject to artifacts involving cytophilic Ig. We have defined a B lymphocyte by three different criteria $(a)$ expression of a high surface density of $\mathrm{Ig}(b)$ expression of a high density of HLA.DR and (c) expression of a marker exclusive to surface $\mathrm{Ig}^{+} \mathrm{B}$ cells. By these criteria, normal individuals have an average of $6 \% \mathrm{~B}$ cells. In multiple myeloma patients, B cell levels in purified mononuclear cell preparations are severely reduced. Untreated patients and the majority of patients on intermittent chemotherapy have 20-600-fold fewer B cells than do normal donors (average $=0.3 \%$ ). This decrease was even greater in whole blood of patients as compared with normal donors (100-1,000-fold fewer B cells). The number of B cells did not correlate with disease status or paraprotein concentration. We found no evidence to support the idea that B lymphocytes in patients include a substantial monoclonal subset.

\section{Introduction}

A deficiency both of normal polyclonal immunoglobulins and functional immunity is common in patients with multiple myeloma (1-6). One potential mechanism is a deficiency of normal B cells. Investigations of B cell number in peripheral blood have yielded conflicting information. Increased, normal, and reduced polyclonal $B$ cell numbers have all been described

Received for publication 6 December 1983 and in revised form 24 May 1984

J. Clin. Invest.

(c) The American Society for Clinical Investigation, Inc.

$0021-9738 / 84 / 10 / 1301 / 06 \$ \$ 1.00$

Volume 74, October 1984, 1301-1306

(7-14). Both an expanded monoclonal lymphocyte pool and an absence of monoclonal lymphocytes related to the malignant plasma cells have also been reported (7-20).

There are two major problems in the study of peripheral blood lymphocytes of patients with multiple myeloma. First, they are bathed in a very high concentration of monoclonal immunoglobulins. Second, the circulating lymphocyte pool may include variable numbers of immunoglobulin secreting cells, depending on the clinical stage of the disease $(21,22)$. Both phenomena could lead to detection of apparent rather than real levels of monoclonal B cells. Thus, in this disorder, any valid study of peripheral blood B cells requires a method of distinguishing between those cells able to actively synthesize surface Ig (sIg) ${ }^{1}$ and those which have passively absorbed serum Ig only. Failure to differentiate between these may explain many of the discrepancies reported in the literature. To overcome the problems of B cell identification we elected to define a B cell as one with a density of sIg sufficient to allow polar movement of receptors to form a cap in an indirect immunofluorescence assay. We further define B lymphocytes by their expression of a high density of HLA-DR and of an antigen expressed exclusively on $\mathrm{sIg}^{+} \mathrm{B}$ cells $(41 \mathrm{H} .16)$.

\section{Methods}

Patients. 51 patients with multiple myeloma were studied. Informed consent was obtained before their participation; 7 were untreated, and 44 had been or were being treated with intermittent chemotherapy during the course of the study. Peripheral blood samples were always obtained at least $4 \mathrm{wk}$ after they had last received therapy. Patients categorized as "off treatment" received their last cycle of chemotherapy at least 6 mo before the time of sampling. A total of 34 normal individuals were included.

Purification of peripheral blood lymphocytes (PBL). Heparinized blood samples were centrifuged and the buffy coat was collected. This was diluted eightfold in commercially prepared RPMI growth medium (Gibco Laboratories, Grand Island, NY) plus 20\% fetal calf serum, and layered over ISOLYMPH (Gallard-Schlesinger Chemical Mfg.

1. Abbreviations used in this paper: FITC, fluorescein isothiocyanate; HGG, human gamma globulin; HLA-DR $T$, high density HLA-DR; $\mathrm{ID}^{+}$, autologous idiotype positive; IF, immunofluorescence; RITC, tetramethylrhodamine isothiocyanate; sIG, surface Ig. 
Corp., Carle Place, NY) followed by centrifugation. The white cells on the RPMI/ISOLYMPH interface were collected, washed three times in RPMI, and subjected to a viable count and a differential count of May Grunwald-Giemsa-stained smears to determine percent lymphocytes in the sample.

Immunofluorescence (IF). For this study the assay method was an indirect IF assay. Purified PBL $\left(5 \times 10^{5}-10^{6}\right)$ were aliquoted into Vbottomed microtiter wells, pelleted, and resuspended in $50 \mu \mathrm{l}$ of the test murine anti-human antibody diluted in normal saline to an appropriate concentration and incubated for $60 \mathrm{~min}$ at $4^{\circ} \mathrm{C}$. Plates were centrifuged, washed twice in saline, and the cell pellet was resuspended in $50 \mu \mathrm{l}$ of a $1 / 20$ dilution of $F\left(a b^{\prime}\right)_{2}$ fragments of sheep anti-mouse Ig labeled with fluorescein isothiocyanate (FITC) or tetramethyl rhodamine isothiocyanate (RITC) (Tago, Inc., Burlingame, CA), incubated for $60 \mathrm{~min}$ at $4^{\circ} \mathrm{C}$, and washed twice. When indicated, cells were resuspended in warm saline and incubated for $10 \mathrm{~min}$ at $37^{\circ} \mathrm{C}$ to allow cap formation (23-25) followed by fixation of cells in $1 \%$ formalin.

IF was examined by using a Zeiss microscope with fluorescence epiillumination and selective filters. Cell samples were counted for total cells in the field and for total number of capped cells by using a hemocytometer. A cell was defined as capped if it had a polar aggregation of fluorescence and at least one-third of the cell lacked fluorescence. The percent capped cells was calculated after screening a minimum of 1,000 cells. In samples with $<0.1 \%$ of caps, a minimum of 5,000 cells were screened.

Antibodies. Mouse anti-human gamma globulin (HGG) was prepared by immunization with commercial HGG by using the procedure of Waters et al. (26) followed by exsanguination between 15 and $21 \mathrm{~d}$ after the initial immunization. Rabbit anti-HGG was prepared by subcutaneous immunization and boosting. Murine anti- $\kappa$, anti- $\lambda$, antiIgD, anti-IgM, anti-IgG, and anti-IgA, were monoclonal antibodies obtained from Bethesda Research Laboratories, Inc., Gaithersburg, MD. 7H.3 is a monoclonal antibody directed to monomorphic HLADR determinants $(27,28)$ and $41 \mathrm{H} .16$ is a monoclonal antibody directed to a 39,000-mol wt B cell maturation antigen expressed on $\mathrm{sIg}^{+}$B cells (29). Both $7 \mathrm{H} .3$ and $41 \mathrm{H} .16$ antibodies were kindly provided by Dr. B. M. Longenecker, Department of Immunology, University of Alberta, Canada, $F\left(a^{\prime}\right)_{2}$ fragments of sheep anti-mouse Ig labeled with FITC or RITC were obtained from Tago, Inc. Goat anti-rabbit Ig (FITC) was from Cappel Laboratories (Cochranville, $P A)$.

Anti-idiotypic antibody was produced by immunization of mice with monoclonal protein that had been purified on protein A or DEAE-columns. The IgG fraction of serum was passed one to two times through Sepharose 4B (Pharmacia Fine Chemicals, Dorval, Quebec) coupled with eight different monoclonal proteins and HGG as described (6), to remove antibody directed against common determinants on Ig and assayed in enzyme-linked immunosorbent assay for specificity.

\section{Results}

$B$ cells in normal PBL. B cells were defined as those cells able to form polar caps as described in the methods. Essentially all cells able to bind our reagents were also able to cap in tests with anti-HGG, anti- $\kappa$, anti- $\lambda$, and anti-B cell antibody $41 \mathrm{H} .16$. In contrast, only a minority of cells with ring fluorescence were able to cap HLA-DR determinants. We performed shedding and resynthesis experiments with normal PBL to determine the percentage of capped cells able both to endocytose and then resynthesize their sIg receptors. Cells able to form caps were also able to resynthesize their receptors after endocytosis (data not shown).

Because the number of HLA-DR-bearing cells able to cap their determinants in an indirect IF assay always correlated closely with the number of $\mathrm{sIg}^{+}$cells, we suspected that this capping subset represented mature $\mathrm{sIg}^{+} \mathrm{B}$ cells. Using double IF, co-capping of both sIg and HLA-DR determinants was found (Table I), indicating that the same subset of PBL express both high density sIg and high density HLA-DR (HLA-DR $\uparrow$ ).

$B$ cell numbers in $P B L$ from normal donors and patients. A panel of antibodies specific for antigenic determinants on $B$ cells included eight antibodies specific for determinants expressed on Ig, one antibody, 7H.3, specific for HLA-DR, and one antibody, $41 \mathrm{H} .16$, specific for an antigen expressed on $\mathrm{sIg}^{+} \mathrm{B}$ cells. Normal PBL include an average of $6-8 \%$ B cells

Table I. Co-capping of sIg and HLA-DR Determinants

\begin{tabular}{|c|c|c|c|}
\hline & \multicolumn{2}{|c|}{ Indicator fluorescent antibody } & \multirow{2}{*}{$\begin{array}{l}\text { \% of caps } \\
\text { with both } \\
\text { FITC and RITC }\end{array}$} \\
\hline & $\begin{array}{l}\text { FITC goat } \\
\text { anti-rabbit Ig }\end{array}$ & $\begin{array}{l}\text { RITC goat } \\
\text { anti-mouse Ig }\end{array}$ & \\
\hline & $\%$ caps & \% caps & \\
\hline \multicolumn{4}{|l|}{ Normal No. 1} \\
\hline \multicolumn{4}{|l|}{ Rabbit } \\
\hline HGG & 4.2 & $<0.08$ & None \\
\hline \multicolumn{4}{|l|}{ Mouse } \\
\hline HLA-DR & $<0.08$ & 7.2 & None \\
\hline $\begin{array}{l}\text { Anti-HGG } \\
\text { plus anti- }\end{array}$ & & & \\
\hline HLA-DR & 7.6 & 7.6 & 100 \\
\hline \multicolumn{4}{|l|}{ Normal No. 2} \\
\hline \multicolumn{4}{|l|}{ Rabbit } \\
\hline HGG & 5 & $<0.08$ & None \\
\hline $\begin{array}{r}\text { Mouse } \\
\text { anti- }\end{array}$ & & & \\
\hline HLA-DR & $<0.08$ & 5.5 & None \\
\hline $\begin{array}{l}\text { Anti-HGG } \\
\text { plus anti- } \\
\text { HLA-DR }\end{array}$ & 4 & 4 & 100 \\
\hline
\end{tabular}

Anti-HLA-DR was monoclonal antibody 7 H.3; anti-HGG was a conventional antiserum. In the samples of lines 3 and 6 , cells were incubated with a mixture of the rabbit and mouse antibodies followed by washing and a second incubation with both the FITC and RITClabeled antibodies. After washing, cells were incubated for $10 \mathrm{~min}$ at $37^{\circ} \mathrm{C}$ to allow capping. $\mathrm{slg}^{+}$caps seen in the doubly stained samples were considerably larger and more clearly defined than in singly stained samples. In the double caps the patterns and extent of fluorescence of red and green caps were completely identical. 
Table II. Percentage of Total PBL Able to Form Caps (n samples)

\begin{tabular}{|c|c|c|c|c|c|c|c|c|c|}
\hline \multirow[b]{2}{*}{ Lymphocytes } & \multicolumn{7}{|l|}{ sIg markers } & \multirow{2}{*}{$\frac{\text { HLA-DR }}{7 \mathrm{H} .3}$} & \multirow{2}{*}{$\begin{array}{l}\text { Mature B } \\
\text { cell marker }\end{array}$} \\
\hline & HGG & $\kappa$ & $\lambda$ & IgD & IgM & $\lg G$ & IgA & & \\
\hline Normal & $\begin{array}{l}6.34 \pm 0.51 \\
(48)\end{array}$ & $\begin{array}{l}4.1 \pm 0.33 \\
(13)\end{array}$ & $\begin{array}{l}3.3 \pm 0.5 \\
(10)\end{array}$ & $\begin{array}{l}3.7 \\
(5)\end{array}$ & $\begin{array}{l}2.9 \pm 0.5 \\
(9)\end{array}$ & $\begin{array}{l}3.4 \pm 0.75 \\
\text { (3) }\end{array}$ & $\begin{array}{l}2.1 \pm 0.5 \\
(4)\end{array}$ & $\begin{array}{l}6.2 \pm 0.53 \\
(33)\end{array}$ & $\begin{array}{l}6.4 \pm 0.58 \\
(20)\end{array}$ \\
\hline $\begin{array}{l}\text { Patients: } \\
\text { all categories }\end{array}$ & $\begin{array}{l}0.7 \pm 0.12 \\
(96)\end{array}$ & $\begin{array}{l}0.69 \pm 0.2 \\
(35)\end{array}$ & $\begin{array}{l}0.5 \pm 0.14 \\
(35)\end{array}$ & - & - & - & - & $\begin{array}{l}0.95 \pm 0.18 \\
(45)\end{array}$ & $\begin{array}{l}1.2 \pm 0.37 \\
(36)\end{array}$ \\
\hline $\begin{array}{r}\text { Untreated } \\
\text { patients }\end{array}$ & $\begin{array}{l}0.3 \pm 0.13 \\
(7)\end{array}$ & $\begin{array}{l}0.28 \pm 0.1 \\
(3)\end{array}$ & $\begin{array}{l}0.06 \pm 0.06 \\
(3)\end{array}$ & $\begin{array}{l}0.1 \\
(2)\end{array}$ & $\begin{array}{r}0.09 \\
(2)\end{array}$ & - & - & $\begin{array}{l}0.54 \pm 0.14 \\
(5)\end{array}$ & $\begin{array}{l}0.69 \pm 0.12 \\
\text { (5) }\end{array}$ \\
\hline $\begin{array}{l}\text { Patients on } \\
\text { treatment }\end{array}$ & $\begin{array}{l}0.29 \pm 0.04 \\
(71)\end{array}$ & $\begin{array}{l}0.47 \pm 0.18 \\
(23)\end{array}$ & $\begin{array}{l}0.55 \pm 0.16 \\
(23)\end{array}$ & $\begin{array}{l}0.15 \pm 0.19 \\
(3)\end{array}$ & $\begin{array}{l}0.26 \pm 0.15 \\
(14)\end{array}$ & - & - & $\begin{array}{l}0.61 \pm 0.12 \\
(34)\end{array}$ & $\begin{array}{l}0.53 \pm 0.1 \\
(23)\end{array}$ \\
\hline $\begin{array}{l}\text { Patients off } \\
\text { treatment }\end{array}$ & $\begin{array}{l}2.3 \pm 0.4 \\
(18)\end{array}$ & $\begin{array}{l}0.94 \pm 0.64 \\
(9)\end{array}$ & $\begin{array}{l}0.46 \pm 0.49 \\
(9)\end{array}$ & $\begin{array}{l}2.8 \pm 0.72 \\
(5)\end{array}$ & $\begin{array}{l}1.45 \pm 0.53 \\
(10)\end{array}$ & $\begin{array}{l}1.4 \pm 0.7 \\
(4)\end{array}$ & $\begin{array}{l}0.97 \pm 0.34 \\
(4)\end{array}$ & $\begin{array}{l}3.1 \pm 0.76 \\
(6)\end{array}$ & $\begin{array}{l}3.7 \pm 0.4 \\
(8)\end{array}$ \\
\hline
\end{tabular}

51 individual patients and 34 individual normal donors were tested one to seven times over a time period of 2 yr. The untreated group consisted of 7 patients, the on-treatment group had 36 patients, and the off-treatment group had 9 patients. Values represent the mean $\pm S E$ of the indicated number of samples.

(Table II). The range of expression in individual samples of PBL is illustrated in Fig. 1.

B cell values for the 51 patients are shown in Table II and individual values are shown in Fig. 1. Untreated patients and

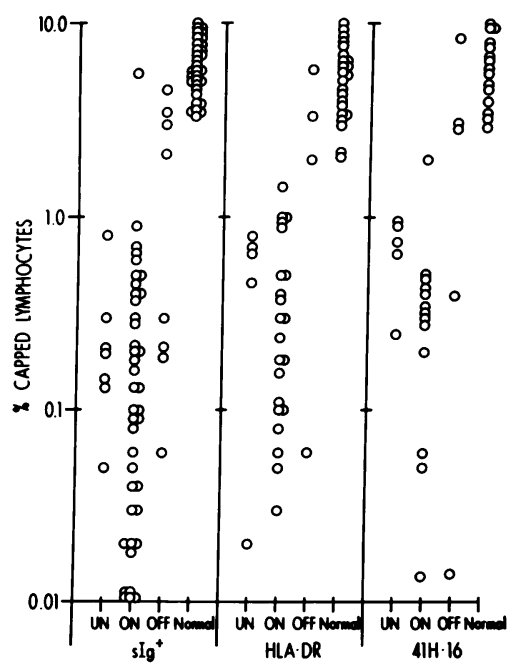

Figure 1. B cell numbers in normal individuals and multiple myeloma patients as defined by expression of SIg, HLA-DR and $41 \mathrm{H} .16$ antigens. Each dot represents the measurement of capped lymphocytes in an individual patient. In cases where a patient was repeatedly assessed, the first test done is represented. Patients that have changed treatment status over the course of assays are represented by a single dot in each treatment category through which they have passed. In the normal donor series, any given individual donor is also included only once. However, it should be emphasized that B cell levels in a given patient are not static, as shown in Fig. 3. those receiving therapy have an average of 20 -fold fewer cells expressing sIg markers and many have a 100-600-fold reduction in number. The number of HLA-DR $\uparrow$ cells and $41 \mathrm{H} .16^{+}$ positive cells is also greatly reduced. In a representative sample of patients, calculations of the actual number of $\mathrm{sIg}^{+}$cells in peripheral blood demonstrates that $B$ cell numbers are even more severely reduced than is apparent from measurements using purified mononuclear cells (Table III).

To ascertain whether the patient B cells were polyclonal in nature, PBL samples were tested for the number of $k$ - and $\lambda$-bearing $B$ cells as well as for expression of IgD, IgM, and in a few cases IgG and IgA. In nearly all individual patient PBL samples tested, the B cell population appeared to be polyclonal in the expression of sIg (Table II and Fig. 2).

Expression of idiotypic determinants on patient and normal $P B L$. To more rigorously test for the presence of a small monoclonal subset of lymphocytes in PBL, anti-idiotypic sera were prepared to the monoclonal protein of three patients. Only small numbers $(0.04-0.08 \%)$ of autologous idiotype positive $\left(\mathrm{Id}^{+}\right)$PBL were detected (Table IV).

Fluctuations of $B$ cell levels in individual patients over time. A series of patients have been assessed for B cell levels on a regular basis over a 1-2-yr period and for comparison, a plot of $B$ cell levels over time in three normal donors have been included (Fig. 3, $A$ and $B$ ). Fig. 3 also demonstrates the lack of correlation of $B$ cell numbers with the concentration of monoclonal protein or stage of disease.

\section{Discussion}

Analysis of $\mathrm{slg}^{+} \mathrm{B}$ cells, as defined by percentage of caps, in 51 multiple myeloma patients, revealed that on average, 
Table III. Number of sIg ${ }^{+}$B Cells in Whole Blood

\begin{tabular}{lllll}
\hline & & & & \\
Source of sample & $\begin{array}{l}\text { No. } \mathrm{slg}^{+} \\
\text {in PBL }\end{array}$ & $\begin{array}{l}\text { Comparative } \\
\text { cells } \times 10^{-3} \\
\text { rer } \mathrm{mm}^{3} \text { blood }\end{array}$ & $\begin{array}{l}\text { Comparative } \\
\text { reduction }\end{array}$ \\
\hline & & fold & & fold \\
Normal & & & & \\
$\quad$ individuals & 6.34 & - & 24 & - \\
& & & $(12-44)$ & \\
Patients & & & & \\
(treatment) & & & & \\
1 (none) & 0.28 & 21 & 0.14 & 171 \\
2 (none) & 0.30 & 20 & 0.48 & 50 \\
3 (off) & 0.30 & 20 & 0.21 & 113 \\
4 (on) & 0.20 & 30 & 0.13 & 185 \\
2 (on) & 0.08 & 75 & 0.08 & 340 \\
5 (on) & 0.15 & 40 & 0.06 & 411 \\
6 (on) & 0.04 & 150 & 0.06 & 411 \\
7 (on) & 0.03 & 200 & 0.02 & 960 \\
8 (on) & 6.0 & None & 14.5 & 1.7 \\
& & & & \\
\hline & & & & \\
\hline
\end{tabular}

Number of $\mathrm{sIg}^{+}$cells in whole blood was calculated from the number of lymphocytes per cubic millimeter of blood (based on a differential count) and the percentage of isolated lymphocytes that were $\mathrm{sIg}^{+}$. In most cases we are able to recover 80-95\% of the lymphocytes in a sample of blood. We have therefore made the assumption that the percentage of PBL that are sIg $^{+}$cells in our purified samples is representative of the percentage in whole blood. In the above noted patients lymphocytes represented from 8 to 39\% of the total white blood cells. The fold of reduction is the number of $\mathrm{sIg}^{+}$cells in normal individuals divided by the number of $\mathbf{s I g}^{+}$cells in patients.

untreated patients and patients on treatment had 20-fold fewer $B$ cells than did normal subjects. The numbers of $B$ cells in individual patients did not correlate with stage of the disease or with the concentration of monoclonal protein. Calculation of the number of $\mathrm{sIg}^{+} \mathrm{B}$ cells in whole blood suggests that the reduction in numbers is even more severe than is apparent in the purified samples (Table III).

As an independent measure of the number of $B$ cells in patients, PBL samples were tested for two further classes of surface marker, high density HLA-DR determinants, and expression of a $B$ cell maturation antigen $41 \mathrm{H}$.16. Two major sets of HLA-DR-positive cells can be distinguished, those that form large very bright polar caps, and those with ring fluorescence. In initial experiments, we demonstrated that in normal subjects cells capping HLA-DR were identical to sIg-capped cells. The low density HLA-DR ${ }^{+}$cells may represent pre-B or B cell subsets expressing an amount of sIg below the limit of detection in our assay system. In patients categorized by treatment status, the pattern of HLA-DR $\uparrow$ and of $41 \mathrm{H} .16$ expression parallelled those of $\mathrm{sIg}^{+}$markers (Table II, Fig. 1).

Thus, by three different criteria: sIg heavy or light chain expression, high density HLA-DR expression, or $41 \mathrm{H} .16$ positivity, most multiple myeloma patients are severely deficient in B cells. Unlike the patient populations examined by some investigators (9), we have been unable to define any patients with supranormal numbers of $\mathrm{sIg}^{+} \mathrm{B}$ cells, and only a minority

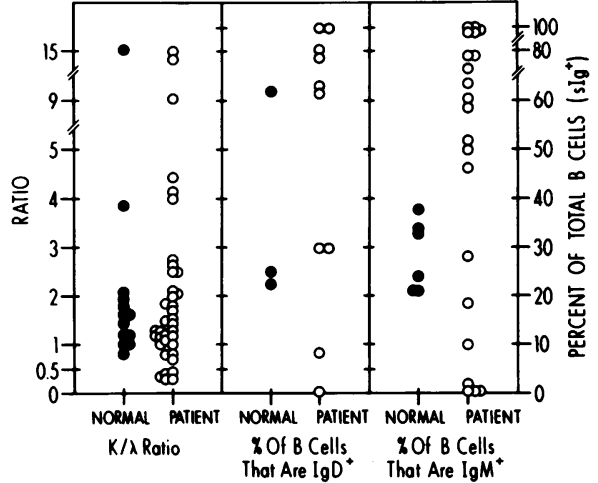

Figure 2. B cells in multiple myeloma patients are polyclonal. Each dot represents an assay on an individual patient, some of whom are represented by more than one dot. Normal individuals may also be represented by more than one dot. This was done to indicate that temporal variations in $B$ cell numbers do not change the polyclonal nature of the B cell population. PBL populations that had been stained with anti-IgD or anti-IgM under capping conditions had bright distinct caps, and cells with ring fluorescence were not observed, indicating that all cells with sufficient sIgM or sIgD to bind our reagents were able to cap.

of patients $(5 / 51)$ had an approximately normal number or exhibited a shift over time from deficient to normal B cell levels. It seems likely that the depression in B cell levels is a major contributory factor to the deficiency in humoral immunity observed in multiple myeloma patients (1-5).

Several research groups have demonstrated substantial numbers of monoclonal B cells in peripheral blood of multiple

Table IV. Expression of Autologous Idiotype on PBL in Multiple Myeloma Patients

\begin{tabular}{|c|c|c|c|c|c|}
\hline \multirow[b]{2}{*}{ Antibody } & \multicolumn{5}{|c|}{$\% \mathrm{Id}^{+} \mathrm{PBL}$} \\
\hline & MD & JRO & $\mathbf{C P}$ & $\begin{array}{l}\text { Other } \\
\text { patients }\end{array}$ & Normal \\
\hline $\begin{array}{l}\text { Mouse } \\
\text { anti-MD }\end{array}$ & $\begin{array}{l}<0.01 \\
<0.01\end{array}$ & $\begin{array}{l}0.04 \\
0.08\end{array}$ & - & $\begin{array}{r}<0.02 ; 0.05 \\
0.06 ; 0.08\end{array}$ & $\begin{array}{r}<0.03 ; 0.01 \\
0.8 ;<0.01\end{array}$ \\
\hline $\begin{array}{l}\text { Mouse } \\
\text { anti-JRO }\end{array}$ & - & $\begin{aligned}<0.02 ; 0.04 \\
0.08 ;<0.01\end{aligned}$ & - & $<0.01 ; 0.01$ & $\begin{array}{l}<0.01 ; 0.04 \\
0.02 ; 0.01 \\
<0.02\end{array}$ \\
\hline $\begin{array}{l}\text { Mouse } \\
\text { anti-CP }\end{array}$ & - & - & 0.05 & 0.09 & $<0.01$ \\
\hline
\end{tabular}

Anti-idiotypic reagents were prepared as described in Methods. Values in columns 5 and 6 are for different individual patients or normal donors. The two MD samples tested had $<0.01$ and $0.2 \%$ sIg $^{+}$cells. JRO samples had $0.1-0.4 \%$ $\mathrm{sIg}^{+}$. The CP sample analyzed had $1.5 \% \mathrm{sk}^{+}$and $1.3 \% \mathrm{~s} \lambda^{+}$cells. $\mathrm{Id}^{+}$caps that were observed were clear-cut and medium-bright. All cells that were stained by the fluorescent sandwich were able to cap and coexisting ring fluorescence was not seen. 

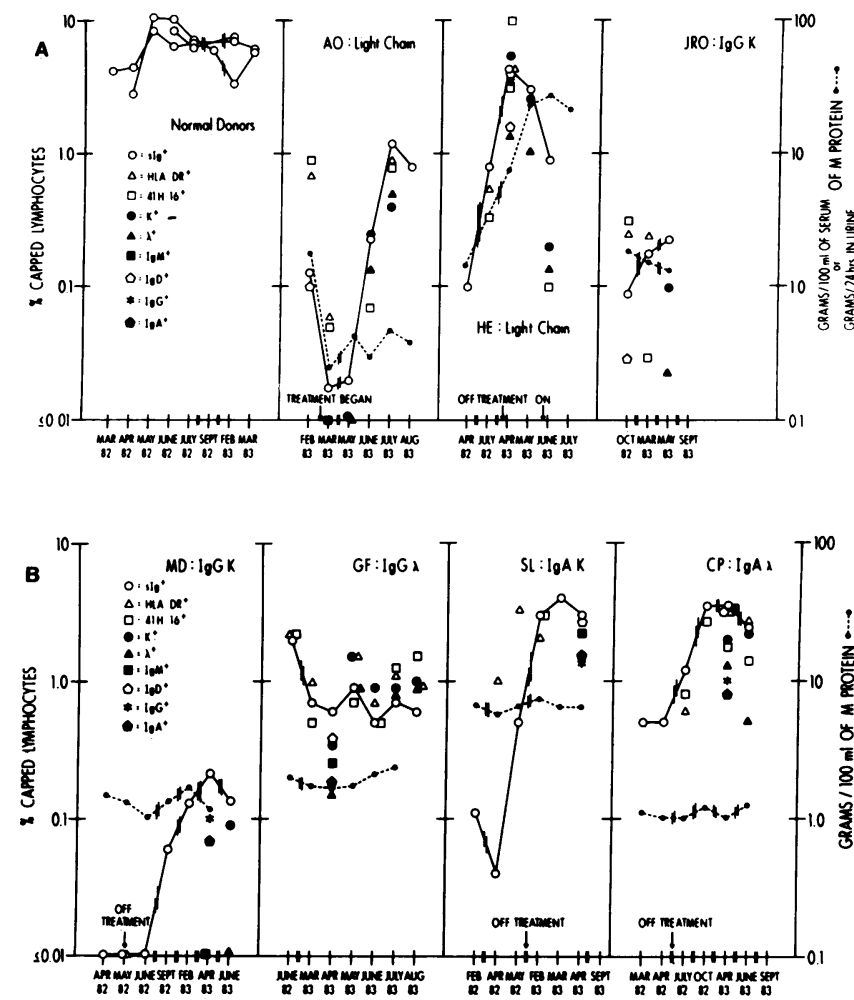

Figure 3. Temporal changes in B cell numbers of individual patients. Patients HE and SL were in the terminal stages of disease (date of death, September 1983), JRO, MD, GF, and CP are asymptomatic, and patient $\mathrm{AO}$ is in a progressive phase of the disease.

myeloma patients either through the use of anti-idiotypic reagents, or analysis of $k / \lambda$ light chain ratios, or of surface heavy chains $(7,8,10-19)$. King and Wells (9) have suggested that in PBL from multiple myeloma patients, cells detected as $\mathrm{Id}^{+}$represent those with passively absorbed Ig. They were unable to detect any endogenous synthesis of $\mathrm{Id}^{+}$receptors even in patients with active disease. However Lindstrom et al. (11) and Abdou and Abdou (13) have detected lymphocytes able to cap the Id in some patients, which suggests that passive absorption of Id is not a universal explanation for observation of monoclonal lymphocytes. In the patients reported here, we have been unable to find any evidence for the existence of large numbers of monoclonal B cells (Fig. 2). Although our methods would not reveal the existence of a small population of monoclonal B cells, the results do indicate that the large numbers reported by others (up to $50 \%$ of total PBL) $(7,10$, 15, 17-19) can not be detected in PBL from the patient population studied here.

Other workers have detected from 3 to $15 \% \mathrm{Id}^{+}$cells in PBL from multiple myeloma patients in remission $(7,10,17$, $19)$ and much larger numbers in relapse patients $(10-47 \%)(7$, $10,13,17)$. In most studies, identification of the $\mathrm{Id}^{+}$cells as
B or T cells has not been established. We have screened PBL samples from three patients in remission for the expression of autologous Id and have been unable to confirm that large numbers of $\mathrm{Id}^{+}$cells exist.

In conclusion, we have established that multiple myeloma patients are severely deficient in an sIg $^{+}$HLA-DR $\uparrow, 41 \mathrm{H} .16^{+}$ subset of B cells. This deficiency is unlikely to be an artifact of treatment as untreated patients also exhibit a deficiency in $\mathrm{sIg}^{+} \mathrm{B}$ cells. We have been unable to detect signs of a large monoclonal B cell pool even in patients with progressive disease. We suggest that the relative lack of $\operatorname{sig}^{+} \mathrm{B}$ cells represents an effect rather than a cause of the disease.

\section{Acknowledgments}

We are grateful to Dr. E. Rapp, University of Calgary for providing access to her patients, and to Ms. Karen Jones, Ms. Maggie Stawarski, and Ms. Pauline Ashley for their help in coordinating patient accrual. We also wish to acknowledge the skilled technical assistance of Ms. D. J. Gibney, and Ms. M. Krezolak. Dr. T. Zipf very generously provided the resources of his laboratory to facilitate transport of blood samples from Calgary to Edmonton.

This work was funded by a grant to Dr. Pilarski from the National Cancer Institute of Canada.

\section{References}

1. Zinneman, H. H., and W. H. Hall. 1954. Recurrent pneumonia in multiple myeloma and some observations on immunologic response. Ann. Int. Med. 41:1152-1163.

2. Cone, L., and J. W. Uhr. 1964. Immunological deficiency disorders associated with chronic lymphocytic leukemia and multiple myeloma. J. Clin. Invest. 43:2241-2248.

3. Fahey, J. L., R. Scoggins, J. P. Utz, and C. F. Szwed. 1963. Infection, antibody response and gamma globulin components in multiple myeloma and macroglobulinemia. Am. J. Med. 35:698-707.

4. Heath, R. B., G. H. Fairley, and J. S. Malpas. 1964. Production of antibodies against viruses in leukaemia and related diseases. $B r . J$. Haematol. 10:365-370.

5. Harris, J., R. Alexanian, E. Hersh, and P. Migliore. 1971. Immune function in multiple myeloma: Impaired responsiveness to keyhole limpet hemocyanin. 1971. Can. Med. Assn. J. 104:389-393.

6. Pruzanski, W., M. S. Gidon, and A. Roy. 1980. Suppression of polyclonal immunoglobulins in multiple myeloma: relationship to the staging and other manifestations at diagnosis. Clin. Immunol. Immunopathol. 17:280-286.

7. Boccadoro, M., A. V. Acker, A. Pileri, and J. Urbain. 1981. Idiotypic lymphocytes in human monoclonal gammopathies. Ann. Immunol. 132C:9-19.

8. Bast, E. J. E. G., B. V. Camp, P. Reynaert, G. Wiringa, and R. E. Ballieux. Idiotypic peripheral blood lymphocytes in monoclonal gammopathy. 1982. Clin. Exp. Immunol. 47:677-682.

9. King, M. A., and J. V. Wells. 1981. Cell-bound immunoglobulin on peripheral blood mononuclear cells of patients with myeloma. Clin. Exp. Immunol. 45:522-556.

10. Holm, G., H. Mellstedt, D. Pettersson, and P. Biberfeld. 1977. Idiotypic immunoglobulin structures on blood lymphocytes in human plasma cell myeloma. Immunol. Rev. 34:139-164. 
11. Lindstrom, F. D., W. R. Hardy, B. J. Eberle, and R. C. Williams. Multiple myeloma and benign monoclonal gammopathy: differentiation by immunofluorescence of lymphocytes. Ann. Intern. Med. 78:837-844.

12. Seligmann, M., J.-L. Preud'Homme, and J.-C. Brouet. 1973. B and $T$ cell markers in human proliferative blood diseases and primary immunodeficiencies, with special reference to membrane bound immunoglobulins. Transplant. Rev. 16:85-113.

13. Abdou, N. I., and N. L. Abdou. 1975. The monoclonal nature of lymphocytes in multiple myeloma. Ann. Intern. Med. 83:42-45.

14. Chen, Y., N. Bhoopalam, V. Yakulis, and P. Heller. 1975. Changes in lymphocyte surface immunoglobulins in myeloma and the effect of an RNA-containing plasma factor. Ann. Intern. Med. 83:625631.

15. Sato, I., T. Abo, S. Onodera, and K. Kumagai. 1978. Detection of monoclonal B lymphocytes in multiple myeloma by immunofluorescence tests of surface immunoglobulins. Scand. J. Haematol. 21:433444.

16. Kubagawa, H., L. B. Vogler, J. D. Capra, M. E. Conrad, A. R. Lawton, and M. D. Cooper. 1979. Studies on the clonal origin on multiple myeloma. J. Exp. Med. 150:792-807.

17. Van Acker, A., F. Conte, N. Hulin, and J. Urbain. 1979. Idiotypic studies on myeloma B cells. Eur. J. Cancer. 15:627-635.

18. Schedel, I., D. Peest, K. Stunkel, M. Fricke, G. Eckert, and H. Deicher. 1980. Idiotype-bearing peripheral blood lymphocytes in human multiple myeloma and Waldenstrom's macroglobulinaemia. Scand. J. Immunol. 11:437-444.

19. Carmagnola, A. L., M. Boccadoro, M. Massaia, and A. Pileri. 1983. The idiotypic specificities of lymphocytes in human monoclonal gammopathies: analysis with the fluorescence activated cell sorter. Clin. Exp. Immunol. 51:173-177.

20. Preud'homme, J.-L., M. Klein, S. Labaume, and M. Seligmann.
1977. Idiotype-bearing and antigen-binding receptors produced by blood T lymphocytes in a case of human myeloma. Eur. J. Immunol. 7:840-846.

21. Shimizu, K., T. Murate, and A. Kunii. 1980. Circulating immunoglobulin-secreting cells in patients with plasma cell dyscrasia. Blood. 55:590-594.

22. Nagai, K., T. Nagai, K. Takatsuki, and H. Uchino. 1982. The effect of anti-la antibody immunoglobulin-secreting cells from healthy individuals and myeloma patients. Scand. J. Immunol. 15:567-571.

23. Unanue, E. R., and M. J. Karnovsky. 1973. Redistribution and fate of Ig complexes on surface of B lymphocytes: functional implications and mechanisms. Transplant. Rev. 14:184-210.

24. Cohen, H. J. 1975. Human lymphocyte surface immunoglobulin capping. J. Clin. Invest. 55:84-93.

25. Kumagai, K., T. Abo, T. Sekizawa, and M. Sasaki. 1975. Studies of surface immunoglobulins on human B lymphocytes. $J$. Immunol. 115:982-987.

26. Waters, C. A., L. M. Pilarski, T. G. Wegmann, and E. Diener. 1979. Tolerance induction during ontogeny. J. Exp. Med. 149:11341151.

27. MacLean, G. D., T. R. Mosmann, J. J. Akabutu, and B. M. Longenecker. 1982. Preference of the early murine immune response for polymorphic determinants on human lymphoid-leukemia cells and the potential use of monoclonal antibodies to these determinants in leukemia-typing panel. Oncodev. Biol. Med. 3:223-232.

28. MacLean, G. D., J. Seehafer, A. R. E. Shaw, M. S. Kieran, and B. M. Longenecker. 1982. Antigenic Heterogeneity of human colorectal cancer cell lines analysed by a panel of monoclonal antibodies. J. Natl. Cancer Inst. 69:357-363.

29. Zipf, T. F., G. J. Lauzon, and B. M. Longenecker. 1983. A monoclonal antibody detecting a 39,000 dalton molecule present on B lymphocytes and chronic lymphocytic leukemia cells but rare on acute lymphocytic leukemia blasts. J. Immunol. 131:3069-3072. 